\title{
PENGARUH STRUKTUR MODAL DAN PERTUMBUHAN PERUSAHAAN, DAN PROFITABILITAS \\ TERHADAP NILAI PERUSAHAAN PADA PERUSAHAAN LQ 45 \\ DI BURSA EFEK INDONESIA PERIODE 2015-2017
}

\author{
THE INFLUENCE OF CAPITAL STRUCTURE, COMPANY GROWTH, AND PROFITABILITY ON \\ CORPORATE VALUE IN LQ 45 COMPANIES IN INDONESIA STOCK EXCHANGE IN 2015-2017
}

\author{
Wawan Anggara $^{1)}$, H. Mukhzarudfa ${ }^{2)}$, Tona Aurora L ${ }^{3)}$ \\ ${ }^{1)}$ Alumni Magister Ilmu Akuntansi Pascasarjana Universitas Jambi Tahun 2019 \\ ${ }^{2,3)}$ Dosen Pembimbing
}

\begin{abstract}
This study aimed to determine the significance of the influence of capital structure, firm growth, and profitability on firm value. The population in this study were all companies included in the $L Q 45$ index registered in Indonesia Stock Exchange in 2015 - 2017. Sampling was carried out using purposive sampling method, whereas the sample was chosen using certain considerations according to the criteria set. Data analysis in this study used panel data analysis with the help of Eviews. The results of this study indicated that the capital structure and the firm growth did not affect the firm value, while profitability had a positive and significant effect on firm value. The results of this study also showed that capital structure, firm growth, and profitability simultaneously affected to the firm value.
\end{abstract}

Keywords: Firm value, capital structure, firm growth, and profitability.

\begin{abstract}
ABSTRAK
Penelitian ini bertujuan untuk mengetahui signifikansi pengaruh struktur modal, pertumbuhan perusahaan, dan profitabilitas terhadap nilai perusahaan. Populasi dalam penelitian ini adalah seluruh perusahaan yang masuk dalam indeks LQ 45 yang terdaftar di Bura Efek Indonesia tahun 2015 - 2017. Pengambilan sampel dilakukan dengan menggunakan metode purposive sampling yaitu sampel dipilih dengan menggunakan pertimbangan tertentu sesuai dengan kriteria yang ditetapkan. Analisis data dalam penelitian ini menggunakan analisis data panel dengan bantuan Eviews. Hasil penelitian ini menunjukkan bahwa struktur modal dan pertumbuhan perusahaan tidak berpengaruh terhadap nilai perusahaan, sedangkan profitabilitas berpengaruh positif dan signifikan terhadap nilai perusahaan. Hasil penelitian ini juga menunjukkan bahwa struktur modal, pertumbuhan perusahaan, dan profitabilitas secara bersama-sama berpengaruh signifikan terhadap nilai perusahaan.
\end{abstract}

Kata kunci: Nilai perusahaan, struktur modal, pertumbuhan perusahaan, dan profitabilitas. 


\section{PENDAHULUAN}

\subsection{Latar Belakang}

Nilai perusahaan merupakan nilai pasar dari suatu ekuitas perusahaan ditambah nilai pasar hutang. Dengan demikan, penambahan dari jumlah ekuitas perusahaan dengan hutang perusahaan dapat mencerminkan nilai perusahaan Berdasarkan penelitian terdahulu, ada beberapa faktor yang dapat mempengaruhi nilai perusahaan, diantaranya: keputusan pendanaan, kebijakan deviden, keputusan investasi, pertumbuhan perusahaan, dan ukuran perusahaan. Beberapa faktor tersebut memiliki hubungan dan pengaruh terhadap nilai perusahaan yang tidak konsisten. (Kusumajaya, 2011).

Berdasarkan teori struktur modal, apabila posisi struktur modal berada di atas target struktur modal optimalnya, maka setiap pertambahan hutang akan menurunkan nilai perusahaan. Esensi trade-off theory dalam struktur modal adalah menyeimbangkan manfaat dan pengorbanan yang timbul sebagai akibat penggunaan hutang. Sejauh manfaat lebih besar, tambahan hutang masih diperkenankan.Apabila pengorbanan karena penggunaan hutang sudah lebih besar, maka tambahan hutang sudah tidak diperbolehkan. Teori trade-off memprediksi hubungan positif antara struktur modal dengan nilai perusahaan dengan asumsi keuntungan pajak masih lebih besar dari biaya tekanan financial dan biaya keagenan. Penelitian Susanti dan Restiana (2018), Andika et.al (2018) dan Antwi (2012) yang membuktikan bahwa struktur modal berpengaruh positif pada nilai perusahaan. Sebaliknya dalam penelitian yang dilakukan oleh Paminto et.al (2016) menunjukkan bahwa struktur modal berpengaruh negatif terhadap nilai perusahaan. Sedangkan penelitian oleh Sudiani dan Wiksuana (2018) dan Hadiwijaya et.al (2016), membuktikan bahwa struktur modal tidak berpengaruh pada nilai perusahaan.

Pertumbuhan perusahaan merupakan faktor lain yang mempengaruhi nilai perusahaan. Perusahaan yang tumbuh cepat juga menikmati keuntungan dari citra positif yang diperoleh, akan tetapi perusahaan harus ekstra hati-hati, karena kesuksesan yang diperoleh menyebabkan perusahaan menjadi rentan terhadap adanya isu negatif. Pertumbuhan cepat juga memaksa sumber daya manusia yang dimiliki untuk secara optimal memberikan kontribusinya. Agar pertumbuhan cepat tidak memiliki arti pertumbuhan biaya yang kurang terkendali, maka dalam mengelola pertumbuhan, perusahaan harus memiliki pengendalian operasi dengan penekanan pada pengendalian biaya. (Kusumajaya, 2011). Penelitian yang dilakukan oleh Fajaria dan Isnalita (2018) menunjukkan bahwa pertumbuhan perusahaan yang tinggi mampu meningkatkan nilai perusahaan. Sebaliknya dalam penelitian yang dilakukan oleh Paminto et.al (2016) menunjukkan bahwa pertumbuhan perusahaan berpengaruh negatif dan signifikan terhadap nilai perusahaan. Sementara itu dalam penelitian yang dilakukan oleh Purwohandoko (2017) menunjukkan bahwa pertumbuhan perusahaan tidak berpengaruh signifikan terhadap nilai perusahaan.

Faktor lain yang mempengaruhi nilai perusahaan yaitu profitabilitas. Menurut Heryetti dan Ekayati (2012), profitabilitas merupakan elemen penting bagi perusahaan yang berorientasi pada laba. Semakin tinggi tingkat profitabilitas yang dicapai perusahaan maka semakin tinggi nilai perusahaan, sehingga untuk meningkatkan nilai perusahaan, perusahaan harus meningkatkan kinerjanya. Penelitian Fajaria dan Isnalita (2018) mengungkapkan bahwa profitabilitas yang tinggi mampu meningkatkan nilai perusahaan karena profit yang tinggi akan memberikan indikasi prospek perusahaan yang baik sehingga dapat memicu investor untuk ikut meningkatkan permintaan saham. Penelitian Fajaria dan Isnalita didukung oleh penelitian Andika et.al (2018), Cheriyta et.al (2017), Tahu dan Susilo (2017), Purwohandoko (2017), Sucuahi dan Cambarihan (2016), Paminto et.al (2016), Sabirin et.al (2016), dan Putu et.al (2014) yang mengungkapkan bahwa profitabilitas berpengaruh positif dan signifikan terhadap nilai perusahaan.

\subsection{Rumusan Masalah}

Berdasarkan latar belakang yang telah dikemukakan di atas, maka yang menjadi permasalahan dalam penelitian ini:

1. Apakah struktur modal berpengaruh signifikan terhadap nilai perusahaan?

2. Apakah pertumbuhan perusahaan berpengaruh signifikan terhadap nilai perusahaan?

3. Apakah profitabilitas berpengaruh signifikan terhadap nilai perusahaan?

4. Apakah struktur modal, pertumbuhan perusahaan, dan profitabilitas secara bersama-sama berpengaruh terhadap nilai perusahaan?

\subsection{Tujuan Penelitian}

Berdasarkan latar belakang tersebut, maka tujuan penelitian ini adalah sebagai berikut:

1. Untuk mengetahui signifikansi pengaruh struktur modal terhadap nilai perusahaan.

2. Untuk mengetahui signifikansi pengaruh pertumbuhan perusahaan terhadap nilai perusahaan.

3. Untuk mengetahui signifikansi pengaruh profitabilitas terhadap nilai perusahaan.

4. Untuk mengetahui signifikansi pengaruh struktur modal, pertumbuhan perusahaan, dan profitabilitas secara bersama-sama terhadap nilai perusahaan. 


\section{TINJAUAN PUSTAKA, KERANGKA PEMIKIRAN DAN HIPOTESIS}

\subsection{Tinjauan Pustaka}

\subsubsection{Nilai Perusahaan}

Nilai diciptakan ketika perusahaan memberikan return kepada para investornya melebihi biaya modal. Nilai untuk investor perusahaan dapat dicapai hanya dengan menyumbangkan nilai kepada customers (Sudana, 2008: 221). Salah satu paradigma baru yang berkembang dalam manajemen untuk menghadapi lingkungan bisnis global, kompetitif, dan turbulen adalah dengan customer value strategy (Mulyadi, 2007: 40). Paradigma customer value strategy memandang bahwa kemampuan perusahaan dalam menghasilkan value terbaik bagi customer merupakan faktor penentu keberhasilan perusahaan untuk bertahan hidup dan bertumbuh dalam lingkungan bisnis global yang kompetitif dan turbulen ini (Mulyadi 2007: 40).

Nilai perusahaan dapat direfleksikan melalui tiga cara, yaitu melalui nilai buku, nilai likuidasi ataupun nilai pasar saham (Husnan dan Pudjiastuti, 2006: 64). Bernard (2003) menyebutkan tiga ukuran dari kinerja perusahaan yang dapat dipakai untuk melihat nilai perusahaan yaitu tobins $\mathrm{Q}$, market to book ratio dan price flow ratio. Nilai dari perusahaan bergantung tidak hanya pada kemampuan menghasilkan arus kas, tetapi juga bergantung pada karakteristik operasional dan keuangan dari perusahaan yang diambil alih.

\subsubsection{Struktur Modal}

Struktur modal merupakan masalah yang penting bagi perusahaan karena baik buruknya struktur modal akan mempunyai efek langsung terhadap posisi finansial perusahaan, terutama dengan adanya hutang yang sangat besar akan memberikan beban kepada perusahaan. Struktur modal menurut Sartono (2010) merupakan perimbangan jumlah utang jangka pendek yang bersifat permanen, utang jangka panjang, saham preferen dan saham biasa. Sementara itu menurut Sudana (2011:143) struktur modal (capital structure) berkaitan dengan pembelanjaan jangka panjang suatu perusahaan yang diukur dengan perbandingan utang jangka panjang dengan modal sendiri.

Struktur modal menurut Fahmi (2011:106) didefinisikan sebagai gambaran dari bentuk proporsi finansial perusahaan yaitu antara modal yang dimiliki yang bersumber dari utang jangka panjang (long-term liabilities) dan modal sendiri (shareholder's equity) yang menjadi sumber pembiayaan suatu perusahaan. Jadi struktur modal merupakan gabungan sumber dana perusahaan yang bersumber dari utang jangka panjang dan modal sendiri yang digunakan sebagai sumber pembiayaan perusahaan.

Dari beberapa definisi yang telah dikemukakan di atas, maka dapat disimpulkan bahwa struktur modal merupakan proporsi keuangan antara utang jangka pendek, utang jangka panjang dan modal sendiri yang digunakan untuk pemenuhan kebutuhan belanja perusahaan.

\subsubsection{Pertumbuhan Perusahaan}

Menurut Setiawan dan Suryono (2015), pertumbuhan perusahaan mengindikasikan kemampuan perusahaan dalam mempertahankan kelangsungan usahanya. Pertumbuhan perusahaan dapat diproksikan dengan pertumbuhan penjualan. Pertumbuhan penjualan digunakan untuk mengukur efektivitas perusahaan dalam mempertahankan posisi ekonominya, baik dalam industri maupun kegiatan ekonomi secara keseluruhan. Swardika (2017) apabila dilihat dari sisi investor, pertumbuhan perusahaan yang baik diharapkan menghasilkan tingkat pengembalian yang lebih banyak atas investasi yang dilakukan. Investor yang memperoleh informasi mengenai pertumbuhan perusahaan yang diindikasikan melalui peningkatan total aktiva dari suatu perusahaan akan mendapat respon baik dari pasar, sehingga hal tersebut dapat meningkatkan harga saham ataupun mencerminkan nilai perusahaan yang meningkat.

Pertumbuhan Perusahaan menunjukkan sejauh mana kemampuan perusahaan untuk tumbuh dan mengembangkan salah satu dari pertumbuhan aset perusahaan. Fahmi (2014) menyatakan bahwa rasio pertumbuhan adalah rasio yang mengukur seberapa besar kemampuan perusahaan untuk mempertahankan posisinya di industri dan perkembangan ekonomi secara umum. Jika manajemen perusahaan dapat memanfaatkan aset perusahaan secara optimal, itu akan meningkatkan laba perusahaan. Semakin efisien penggunaan aset perusahaan, semakin rendah biaya yang diperlukan untuk mendanai operasi aset. Semakin efektif penggunaan aset perusahaan, semakin rendah kemungkinan aset tidak digunakan. Aset yang tidak digunakan dapat dijual, sehingga perusahaan akan menerima dana tambahan. Dalam menilai pertumbuhan perusahaan dapat menggunakan perhitungan Total Asset Growth (TAG). Total aset menunjukkan proyeksi pertumbuhan potensi pertumbuhan perusahaan antara tahun berjalan dengan tahun sebelumnya.

\subsubsection{Profitabilitas}

Profitabilitas adalah kemampuan perusahaan dalam menghasilkan laba. Menurut Sartono (2010), profitabilitas adalah kemampuan perusahaan memperoleh laba dalam hubungannnya dengan penjualan, total aktiva maupun modal sendiri. Para investor tetap tertarik terhadap profitabilitas perusahaan karena profitabilitas mungkin merupakan satu-satunya indikator yang paling baik mengenai kesehatan keuangan perusahaan.

Profitabilitas perusahaan merupakan salah satu cara untuk menilai secara tepat sejauh mana tingkat pengembalian yang akan didapat dari aktivitas investasi. Jika kondisi perusahaan dikategorikan menguntungkan atau menjanjikan keuntungan dimasa mendatang maka banyak investor yang akan menanamkan dananya untuk membeli saham 
perusahaan tersebut. Hal itu tentu saja akan mendorong harga saham naik menjadi lebih tinggi. Profitabilitas adalah hasil akhir dari sejumlah kebijakan dan keputusan manajemen perusahaan (Novianto, 2016).

\subsection{Kerangka Pemikiran}

Menurut Syardiana et al (2015) Struktur modal terkait dengan harga saham. Aturan struktur finansial konservatif menghendaki agar perusahaan tidak mempunyai hutang yang lebih besar daripada jumlah modal sendiri, dalam keadaan bagaimanapun. Debt Equity Ratio mencerminkan kemampuan perusahaan dalam memenuhi seluruh kewajibannya yang ditunjukkan oleh modal sendiri yang digunakan sebagai pembayaran hutang. Semakin tinggi hutang (DER) maka resiko yang ditanggung juga besar. Hal ini akan mempengaruhi kepercayaan investor terhadap perusahaan dan selanjutnya akan mempengaruhi nilai perusahaan. Penelitian ini pernah pula dilakukan oleh Rosje dan Astuti (2003) yang dalam hasil penelitiannya mengemukakan bahwa Debt Equity Ratio (DER) tidak berpengaruh terhadap nilai perusahaan (PBV).

Perusahaan yang menghadapi kesempatan pertumbuhan yang rendah, maka rasio hutang berhubungan secara positif dengan nilai perusahaan. Sedangkan perusahaan yang menghadapi kesempatan pertumbuhan yang tinggi, maka rasio hutang berhubungan secara negatif dengan nilai perusahaan.
Oleh karena itu, pengaruh hutang terhadap nilai perusahaan sangat tergantung pada keberadaan kesempatan pertumbuhan. Pertambahan perubahan total aktiva periode penelitian ini mempengaruhi harga perlembar saham terhadap ekuitas perlembar saham di kalangan investor (Saputri Dewi dkk, 2014).

Rasio profitabilitas atau rasio rentabilitas menunjukkan keberhasilan perusahaan dalam menghasilkan keuntungan. Dalam penelitian iniprofitabilitas diukur dengan return on equity merupakan rasio yang sangat penting bagi pemilik perusahaan (the common stockholder), karena rasio ini menunjukkan tingkat kembalian yang dihasilkan oleh manajemen dari modalyang disediakan oleh pemilik perusahaan. Semakin tinggi nilai profit yang didapat maka akan semakin tinggi nilai perusahaan. Karena profit yang tinggi akan memberikan indikasi prospek perusahaan yang baik sehingga dapat memicu investor untuk ikut meningkatkan permintaan saham. Permintaan saham yang meningkat akan menyebabkan nilai perusahaan yang meningkat. (Mardiyati U, dkk, 2012; Mahatma Dewi AS dan Wirajaya A.2013).

Untuk membantu dalam memahami peran variabel yang mempengaruhi Nilai Perusahaan, maka diperlukan suatu kerangka pemikiran dan model penelitian sebagai berikut:

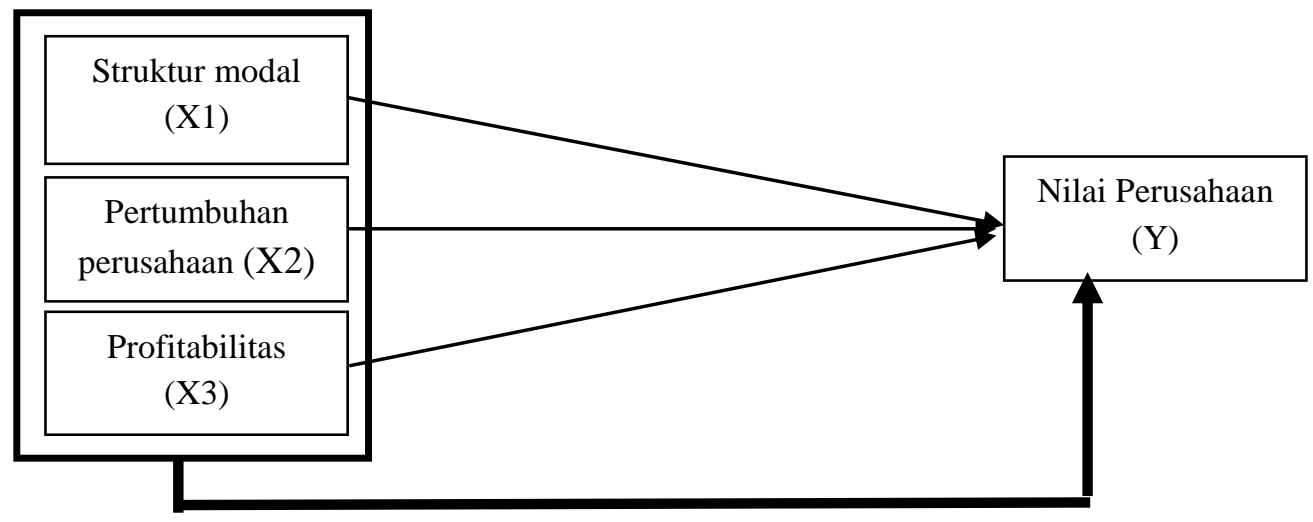

Gambar 1. Model Kerangka pemikiran

\subsection{Hipotesis}

Berdasarkan kajian pustaka dan hasil penelitian emperik yang telah dilakukan sebelumnya, maka hipotesis untuk penelitian ini sebagai berikut:

$\mathrm{H}_{1}$ : Struktur Modal berpengaruh terhadap Nilai Perusahaan.

$\mathrm{H}_{2}$ : Pertumbuhan Perusahaan berpengaruh terhadap Nilai Perusahaan.

$\mathrm{H}_{3}$ : Profitabilitas berpengaruh terhadap Nilai Perusahaan

$\mathrm{H}_{4}$ : Struktur modal, pertumbuhan perusahaan, dan profitabilitas secara bersama-sama berpengaruh terhadap Nilai Perusahaan

\section{METODOLOGI PENELITIAN}

\subsection{Jenis Penelitian}

Penelitian ini merupakan penelitian kuantitatif bersifat hubungan causal explanatory yang bertujuan mengetahui pola hubungan kausal antara variabel independen dan variabel dependen. Penggunaan metode causal explanatory sesuai dengan tujuan penelitian yaitu melakukan pengujian hipotesa yang menguji hubungan dan pengaruh diantara variabel yang diteliti. Pemilihan jenis penelitian ini sesuai dengan tujuan penelitian, yaitu untuk mengetahui apakah struktur kepemilikan dan struktur pengelolaan berpengaruh terhadap manajemen laba riil. 


\subsection{Populasi dan Sampel}

Populasi dalam penelitian ini adalah seluruh perusahaan yang masuk dalam indeks LQ 45 yang terdaftar di Bura Efek Indonesia tahun 2015 - 2017. Pengambilan sampel dilakukan dengan menggunakan metode purposive sampling yaitu sampel dipilih dengan menggunakan pertimbangan tertentu sesuai dengan kriteria yang ditetapkan.

Proses purposive sampling dalam penelitian dapat dilihat pada tabel berikut ini :

Tabel 1. Proses Purposive Sampling Penelitian

\begin{tabular}{|c|c|c|}
\hline No & Purposive Sampling & Jumlah \\
\hline 1 & Perusahaan LQ-45 di BEI & 45 \\
\hline 2 & $\begin{array}{l}\text { Dikurangi Perusahaan yang tidak konsisten bergabung di LQ-45 berturut- } \\
\text { turut selama periode } 2015-2017 \text {. }\end{array}$ & (10) \\
\hline 3 & Dikurangi perusahaan keuangan & (5) \\
\hline \multicolumn{2}{|r|}{ Jumlah } & 30 \\
\hline
\end{tabular}

\subsection{Variabel Penelitian}

Variabel dalam penelitian ini antara lain yaitu:

1. Variabel Bebas ( Independent Variable )

Variabel bebas dalam penelitian ini adalah

Struktur Modal (X1) Pertumbuhan Perusahaan

(X2) dan Profitabilitas (X3).
2. Variabel Terikat ( Dependent Variable)

Variabel terikat yang akan diteliti adalah Nilai Perusahaan (Y).

Tabel 2. Operasionalisasi Variabel Penelitian

\begin{tabular}{|c|l|l|l|}
\hline Variabel & \multicolumn{1}{|c|}{ Definisi/Konsep Variabel } & \multicolumn{1}{c|}{$\begin{array}{c}\text { Indikator } \\
\text { pengukuran }\end{array}$} & $\begin{array}{c}\text { Skala } \\
\text { Pengukuran }\end{array}$ \\
\hline $\begin{array}{c}\text { Nilai Perusahaan } \\
(\mathrm{Y})\end{array}$ & $\begin{array}{l}\text { Sama dengan nilai pasar saham } \\
\text { ditambah pasar hutang (Kusumajaya, } \\
\text { 2011) }\end{array}$ & $\begin{array}{l}\text { Price to Book Value } \\
\text { (PBV) }\end{array}$ & Rasio \\
\hline $\begin{array}{c}\text { Struktur Modal } \\
\left(\mathrm{X}_{1}\right)\end{array}$ & $\begin{array}{l}\text { Perimbangan atau perbandingan antara } \\
\text { jumlah hutang jangka panjang dengan } \\
\text { modal sendiri (Robert, 1997) }\end{array}$ & $\begin{array}{l}\text { Debt to Equity Ratio } \\
\text { (DER) }\end{array}$ & Rasio \\
\hline Pertumbuhan & $\begin{array}{l}\text { Dampak atas arus dana perusahaan dari } \\
\text { perubahan operasional yang disebabkan } \\
\text { Perusahaan }\left(\mathrm{X}_{2}\right) \\
\text { volume usaha (Helfert, 1997) }\end{array}$ & $\begin{array}{l}\text { Perubahan total } \\
\text { aktiva. }\end{array}$ & Rasio \\
\hline $\begin{array}{l}\text { Profitabilitas } \\
\text { (X3) }\end{array}$ & $\begin{array}{l}\text { Kemampuan memperoleh laba dalam } \\
\text { hubungannya dengan penjualan, total } \\
\text { aktiva maupun modal sendiri } \\
\text { (Syamsuddin, 2007) }\end{array}$ & $\begin{array}{l}\text { Return On Equity } \\
\text { (ROE) }\end{array}$ & Rasio \\
\hline
\end{tabular}

\subsection{Teknik Analisis Data}

Penelitian ini menggunakan analisis deskriptif kuantitatif dan analisis data panel untuk menjawab permasalahan yang sudah dirumuskan sebelumnya. Data panel adalah data yang memiliki jumlah cross section dan jumlah time series. Persamaan regresi dengan analisis data panel yang digunakan dalam penelitian ini adalah:

$Y=\alpha+\beta_{1} X_{1}+\beta_{2} X_{2}+\beta_{3} X_{3}+e$

Dimana:

$\mathrm{Y}=$ Nilai Perusahaan

$\alpha=$ Konstanta

$\beta_{1}=$ Koefisien regresi dari Struktur Modal

$\mathrm{X}_{1}=$ Struktur Modal

$\beta_{2}=$ Koefisien regresi dari Pertumbuhan Perusahaan

$\mathrm{X}_{2}=$ Pertumbuhan Perusahaan

$\beta_{3}=$ Koefisien regresi dari Profitabilitas

$\mathrm{X}_{3}=$ Profitabilitas

$\mathrm{e}=$ Faktor Kesalahan

\subsubsection{Pemilihan Metode Estimasi Analisis Data Panel}

Analisis data panel dilakukan menggunakan tiga pendekatan untuk mengestimasi, antara lain dengan metode common effect, fixed effect dan random effect. Oleh karena itu perlu melakukan pengujian untuk menentukan mana diantara ketiga pendekatan tersebut yang paling sesuai dengan data yang digunakan.

1) Pengujian Antara Metode Common Effect atau Metode Fixed Effect

Pengujian model terbaik antara menggunakan metode common effect atau dengan menggunakan metode individual effect (yang diawali oleh model fixed effect) menggunakan redundant fixed effect test terlebih dahulu membuat hipotesis:

$H_{0}: \alpha 1=\alpha 2=\alpha 3=\ldots=\alpha \mathrm{i}$, Common Effect

$H_{a}: \alpha 1 \neq \alpha 2 \neq \alpha 3 \neq \ldots \neq \alpha \mathrm{i}$, Individual Effect

Pengambilan keputusan apakah $\mathrm{H}_{0}$ atau $\mathrm{H}_{\mathrm{a}}$ yang diterima yaitu dengan membandingkan hasil 
$F_{\text {hitung dengan }} F_{\text {tabel. }} F_{\text {tabel }}$ dicari pada $\alpha$ tertentu untuk m numerator df dan (n-k) dominator df. Jika $\mathrm{F}_{\text {hitung }}$ lebih besar dari $\mathrm{F}_{\text {tabel }}$ maka $\mathrm{H}_{0}$ ditolak sehingga $\mathrm{H}_{0}$ diterima artinya model yang digunakan adalah individual effect (fixed effect). Sebaliknya jika $\mathrm{F}_{\text {hitung }}$ lebih kecil dari $\mathrm{F}_{\text {tabel }}$ maka $\mathrm{H}_{0}$ diterima sehingga $\mathrm{H}_{\mathrm{a}}$ ditolak yang artinya model yang digunakan adalah common effect.

2) Pengujian Antara Metode Fixed Effect atau Metode Random Effect

Pengambilan keputusan apakah menggunakan fixed effect atau random effect dilakukan dengan menggunakan haustman test. Dilihat dengan menggunakan nilai probability ( $p$-value) sehingga keputusan pemilihan kedua model tersebut akan dapat ditentukan secara statistik. Sebelum melakukan pengujian yang pertama kita membuat hipotesis dulu:

$\mathrm{H}_{0}$ : Ada gangguan antar individu (random effect)

$\mathrm{H}_{\mathrm{a}}$ : Tidak ada gangguan antar individu (fixed effect)

Pengambilan keputusan didasarkan pada membandingkan hasil haussman test ini, dimana jika $p$-value lebih kecil 0,05 , maka $\mathrm{H}_{0}$ ditolak dan $\mathrm{H}_{\mathrm{a}}$ diterima, berarti analisis yang digunakan yaitu metode fixed effect. Sebaliknya jika $p$-value lebih besar dari 0,05, maka $\mathrm{H}_{0}$ diterima dan $\mathrm{H}_{\mathrm{a}}$ ditolak, berarti analisis yang digunakan yaitu dengan metode random effect.

3) Pengujian Antara Metode Common Effect atau Metode Random Effect

Pengambilan keputusan apakah menggunakan common effect atau random effect dilakukan dengan menggunakan langrange multiplier (LM) test. Dilihat dengan menggunakan nilai probability ( $p$ value) sehingga keputusan pemilihan kedua model tersebut akan dapat ditentukan secara statistik. Sebelum melakukan pengujian yang pertama kita membuat hipotesis dulu:

$\mathrm{H}_{0}$ : Menerima penggunaan metode common effect

$\mathrm{H}_{\mathrm{a}}$ : Menerima penggunaan metode random effect

Pengambilan keputusan didasarkan pada membandingkan hasil LM-Test, dimana jika $p$-value lebih kecil 0,05 , maka $\mathrm{H}_{0}$ ditolak dan $\mathrm{H}_{\mathrm{a}}$ diterima, berarti analisis yang digunakan yaitu metode random effect. Sebaliknya jika $p$-value lebih besar dari 0,05 , maka $\mathrm{H}_{0}$ diterima dan $\mathrm{H}_{\mathrm{a}}$ ditolak, berarti analisis yang digunakan yaitu dengan metode common effect.

\subsubsection{Pengujian Hipotesis}

Analisis ini digunakan untuk mengetahui apakah semua variabel independen mempunyaipengaruh terhadap variabel dependen. Metode pengujian terhadap hipotesis yang diajukan dilakukan pengujian secara parsial dan pengujian secara simultan serta analisis koefisien derteminasi $\left(\mathrm{R}^{2}\right)$. Pengujian hipotesis tersebut sebagai berikut:

1) Uji Statistik $t$

Uji t dipergunakan untuk mengukur secara parsial pengaruh variabel bebas (X) terhadap variabel terikat (Y). Uji ini dilakukan dengan membandingkan signifikansi t hitung dengan t tabel dengan ketentuan sebagai berikut:

Jika $\mathrm{t}_{\text {hitung }} \leq \mathrm{t}_{\text {tabel}}$, atau $-\mathrm{t}_{\text {hitung }} \geq-\mathrm{t}_{\text {tabel }}$, maka $\mathrm{H} 0$ diterima.

Jika $\mathrm{t}$ hitung $>\mathrm{t}$ tabel, atau $-\mathrm{t}$ hitung $<-\mathrm{t}$ tabel, maka Ha diterima.

2) Uji Statistik F

Uji $F$ dipergunakan untuk mengukur secara simultan pengaruh semua variabel bebas terhadap variabel terikat (Y). Uji ini dilakukan dengan membandingkan signifikansi $\mathrm{F}$ hitung dengan $\mathrm{F}$ table dengan ketentuan sebagai berikut:

Jika $\mathrm{F}_{\text {hitung }} \leq \mathrm{F}_{\text {tabel }}$, maka $\mathrm{H} 0$ diterima

Jika $\mathrm{F}_{\text {hitung }}>\mathrm{F}_{\text {tabel }}$, maka Ha diterima

3) Koefisien Determinasi $\left(R^{2}\right)$

Koefisien determinasi $\left(\mathrm{R}^{2}\right)$ pada intinya mengukur seberapa jauh kemampuan model dalam menerangkan variasi variabel dependen. Dalam penelitian ini digunakan nilai Adjusted $R^{2}$. Nilai Adjusted $R^{2}$ dapat naik atau turun apabila satu variabel independen ditambahkan ke dalam model.

\section{HASIL DAN PEMBAHASAN}

\subsection{Hasil Penelitian}

\subsubsection{Pemilihan Model Analisis Data Panel}

Pemilihan model analisis data panel yang digunakan akan mempengaruhi hasil estimasi yang dilakukan dalam penelitian. Untuk menentukan hasil analisis data panel terbaik pada penelitian ini, maka terlebih dahulu dilakukan pemilihan model yang sesuai dengan data penelitian dengan langkah-langkah sebagai berikut:

1. Pemilihan Antara Model Common Effect atau Model Fixed Effect

Pemilihan model estimasi common effect dan fixed effect dilakukan dengan menggunakan redundant fixed effect test dengan hasil sebagai berikut:

Tabel 3. Redundant Fixed Effect Test

\begin{tabular}{lrrr}
\hline \hline Effects Test & \multicolumn{1}{c}{ Statistic } & d.f. & Prob. \\
\hline \hline Cross-section F & 3.418256 & $(29,57)$ & 0.0000 \\
Cross-section Chi-square & 90.687069 & 29 & 0.0000
\end{tabular}


Berdasarkan tabel 3 di atas didapatkan nilai Probability Cross-section $F=0,000$ lebih kecil dari taraf signifikansi 0,05 . Hal ini berarti $\mathrm{H}_{0}$ diterima dan Ha ditolak. Dengan demikian pada model data panel terdapat gangguan individu atau dengan kata lain bahwa analisis sebaiknya menggunakan model fixed effect daripada model common effect.
2. Pemilihan Antara Model Random Effect atau Model Fixed Effect

Pengambilan keputusan apakah menggunakan model fixed effect atau menggunakan model random effect dilakukan dengan menggunakan haussman test. Hasil pengujian haussman test adalah sebagai berikut:

Tabel 4. Hasil Uji Haussman Test

\begin{tabular}{|c|c|c|c|}
\hline Test Summary & Chi-Sq. Statistic & Chi-Sq. d.f. & Prob. \\
\hline Cross-section random & 2.933504 & 3 & 0.4020 \\
\hline
\end{tabular}

Sumber: Hasil pengolahan data, 2019

Berdasarkan tabel 4 di atas dapat dilihat bahwa p-value yaitu 0,4020 lebih besar dari 0,05. Hal ini berarti $\mathrm{H}_{0}$ diterima dan $\mathrm{H}_{\mathrm{a}}$ ditolak, yang berarti asumsi penerimaan model fixed effect ditolak dan menerima asumsi penggunaan model random effect.

3. Pemilihan Antara Model Common Effect atau Model Random Effect

Berdasarkan hasil pemilihan model sebelumnya, menunjukkan bahwa hasil redundant fixed effect test menunjukkan bahwa model yang sebaiknya digunakan adalah model fixed effect, sedangkan berdasarkan hasil haussman test menunjukkan bahwa model analisis yang sebaiknya digunakan adalah model random effect. Oleh karena itu, diperlukan pemilihan model antara common effect dengan random effect, model mana dari kedua model tersebut yang lebih tepat digunakan dalam penelitian ini. Pemilihan model estimasi common effect dan random effect dilakukan dengan menggunakan langrange multiplier test dengan hasil sebagai berikut:

Tabel 5. Langrange Multiplier Test

\begin{tabular}{|c|c|c|c|}
\hline & Cross-section & $\begin{array}{l}\text { st Hypothes } \\
\text { Time }\end{array}$ & Both \\
\hline Breusch-Pagan & $\begin{array}{l}15.95942 \\
(0.0001)\end{array}$ & $\begin{array}{l}1.474788 \\
(0.2246)\end{array}$ & $\begin{array}{l}17.43421 \\
(0.0000)\end{array}$ \\
\hline
\end{tabular}

Sumber: Hasil pengolahan data, 2019

Berdasarkan tabel 5 di atas didapatkan nilai probability Breusch Pagan (Both) sebesar 0,0000 lebih kecil dari taraf signifikansi 0,05. Hal ini berarti $\mathrm{H}_{0}$ ditolak dan $\mathrm{Ha}$ diterima, dengan demikian bahwa analisis yang digunakan sebaiknya adalah model random effect dan menolak penggunaan model analisis common effect.

Tabel 6. Hasil Analisis Regresi Data Panel Menggunakan Model Random Effect

\begin{tabular}{crrrr}
\hline \hline \multicolumn{1}{c}{ Variable } & Coefficient & Std. Error & t-Statistic & Prob. \\
\hline C & -3.085893 & 1.365796 & -2.259409 & 0.0264 \\
DER & 0.594057 & 0.578995 & 1.026015 & 0.3078 \\
PERTUMBUHAN & -0.001304 & 0.010758 & -0.121174 & 0.9038 \\
ROE & 0.380815 & 0.071875 & 5.298286 & 0.0000 \\
\hline \hline R-squared & & & \\
Adjusted R-squared & 0.783013 & Mean dependent var & 3.376303 \\
S.E. of regression & 0.775443 & S.D. dependent var & 8.045590 \\
F-statistic & 3.812598 & Sum squared resid & 1250.088 \\
R & 103.4454 & Durbin-Watson stat & 2.190210
\end{tabular}

\subsubsection{Analisis Data Panel dengan Metode Random Effect}

Hasil analisis data panel dengan model estimasi random effect digambarkan dalam tabel berikut ini: 
Sumber: Hasil pengolahan data, 2019

Berdasarkan tabel 6 di atas, dari koefisien regresi dibentuk persamaan regresi sebagai berikut:

PBV $=-3,085893+0,594057$ DER - 0,001304 PERTUMBUHAN + 0,380815 ROE

Berdasarkan tabel di atas dapat dirumuskan halhal sebagai berikut:

1. Nilai konstan $(c)=-3,085893$, berarti bahwa pada saat struktur modal, pertumbuhan perusahaan, dan profitabilitas sama dengan 0 , maka nilai perusahaan bernilai negatif sebesar 3,085893 satuan.

2. Koefisien regresi variabel struktur modal bernilai positif sebesar 0,594057, hal ini memperlihatkan bahwa apabila struktur modal perusahaan LQ-45 di BEI tahun 2015 - 2017 meningkat sebesar 1 satuan, maka akan terjadi peningkatan nilai perusahaan sebesar 0,594057 satuan pada saat variabel yang lain diasumsikan konstan.

3. Koefisien regresi variabel pertumbuhan perusahaan bernilai negatif sebesar 0,001304, hal ini memperlihatkan bahwa apabila pertumbuhan perusahaan pada perusahaan LQ-45 di BEI tahun 2015 - 2017 meningkat sebesar 1\%, maka akan terjadi penurunan nilai perusahaan sebesar 0,001304 satuan pada saat variabel yang lain diasumsikan konstan.

4. Koefisien regresi variabel profitabilitas bernilai positif sebesar 0,380815 , hal ini memperlihatkan bahwa apabila nilai profitabilitas perusahaan LQ45 di BEI tahun 2015 - 2017 meningkat sebesar $1 \%$, maka akan terjadi peningkatan nilai perusahaan sebesar 0,380815 satuan pada saat variabel yang lain diasumsikan konstan.

\subsubsection{Hasil Pengujian Hipotesis}

Pengujian hipotesis dilakukan untuk melihat signifikansi pengaruh struktur modal, pertumbuhan perusahaan, dan profitabilitas secara parsial dan simultan terhadap nilai perusahaan. Pengujian hipotesis simultan dilakukan dengan menggunakan uji $F$. Sedangkan pengujian hipotesis secara parsial dilakukan dengan menggunakan uji t. Hasil pengujian hipotesis secara simultan dan secara parsial yaitu sebagai berikut:

\section{Hasil Uji t (Uji Parsial)}

Nilai $t_{\text {hitung }}$ merupakan nilai yang didapat dengan membandingkan koefisien regresi tiap variabel dengan standar error dari koefisien regresi tersebut. Kriteria keputusan dilihat nilai probabilitas dari setiap koefisien regresi masing-masing variabel independen. Hasil uji t dapat dilihat pada tabel 6 di atas. a. Pengujian pengaruh struktur modal terhadap nilai perusahaan

Pada variabel struktur modal, nilai $t_{\text {hitung }}$ sebesar 1,026015 , sedangkan $t_{\text {tabel }}$ pada taraf signifikansi 0,05 dengan $\mathrm{df}=\mathrm{N}-\mathrm{k}=90-3=87$ sebesar 1,987, $t_{\text {hitung }}<t_{\text {tabel}}$, yang berarti bahwa $\mathrm{H}_{0}$ diterima dan dan $\mathrm{H}_{\mathrm{a}}$ ditolak, dengan demikian struktur modal tidak memiliki pengaruh yang signifikan terhadap nilai perusahaan pada perusahaan LQ-45 di BEI tahun 2015 - 2017.

b. Pengujian pengaruh pertumbuhan perusahaan terhadap nilai perusahaan

Pada variabel pertumbuhan perusahaan, nilai $t_{\text {hitung }}$ sebesar 0,121174 , sedangkan $t_{\text {tabel }}$ pada taraf signifikansi 0,05 dengan $\mathrm{df}=\mathrm{N}-\mathrm{k}=90-$ $3=87$ sebesar $1,987, t_{\text {hitung }}<t_{\text {tabel }}$, yang berarti bahwa $\mathrm{H}_{0}$ diterima dan dan $\mathrm{H}_{\mathrm{a}}$ ditolak, dengan demikian pertumbuhan perusahaan tidak memiliki pengaruh yang signifikan terhadap nilai perusahaan pada perusahaan LQ-45 di BEI tahun 2015 - 2017.

c. Pengujian pengaruh profitabilitas terhadap nilai perusahaan

Pada variabel profitabilitas, nilai $t_{\text {hitung }}$ sebesar 5,298286 , sedangkan $t_{\text {tabel }}$ pada taraf signifikansi 0,05 dengan $\mathrm{df}=\mathrm{N}-\mathrm{k}=90-3=87$ sebesar $1,987, t_{\text {hitung }}>t_{\text {tabel }}$, yang berarti bahwa $\mathrm{H}_{0}$ ditolak dan dan $\mathrm{H}_{\mathrm{a}}$ diterima, dengan demikian profitabilitas memiliki pengaruh yang signifikan terhadap nilai perusahaan pada perusahaan LQ45 di BEI tahun 2015 - 2017.

\section{Hasil Uji F (Uji Simultan)}

Hasil uji $\mathrm{F}$ yang dilakukan untuk melihat pengaruh struktur modal, pertumbuhan perusahaan, dan profitabilitas secara bersama-sama terhadap nilai perusahaan digambarkan dalam tabel 6. Dari tabel 6 di atas didapat nilai $F_{\text {hitung }}$ sebesar 103,4454, sedangkan $F_{\text {tabel }}$ pada taraf signifikansi 0,05 sebesar 1,666, hal ini berarti bahwa $\mathrm{H}_{0}$ ditolak dan dan $\mathrm{H}_{\mathrm{a}}$ diterima. Ini menunjukkan bahwa semua variabel independen yaitu struktur modal, pertumbuhan perusahaan, dan profitabilitas secara bersama-sama memiliki pengaruh yang signifikan terhadap nilai perusahaan.

\section{Koefisien Determinasi}

Besarnya pengaruh struktur modal, pertumbuhan perusahaan, dan profitabilitas terhadap nilai perusahaan dapat dilihat pada nilai koefisien determinasi (adjusted $R^{2}$ ) dalam tabel 6 di atas. Dari tabel 6 dapat dilihat bahwa besarnya koefisien determinasi (Adjusted $R^{2}$ ) yaitu sebesar 0,775443. Besarnya pengaruh yaitu $0,775443 \times 100 \%=$ $77,5443 \%$, dan sisanya sebesar $22,4557 \%$ dipengaruhi oleh faktor lain yang tidak termasuk dalam variabel penelitian. 
4.2. Pembahasan

4.2.1 Pengaruh Struktur Modal terhadap Nilai Perusahaan pada Perusahaan LQ-45 di Bursa Efek Indonesia Tahun 2015 - 2017

Hasil penelitian ini menunjukkan bahwa struktur modal tidak memiliki pengaruh yang signifikan terhadap nilai perusahaan pada perusahaan LQ-45 di BEI tahun 2015 - 2017. Hal ini dibuktikan dari hasil pengujian hipotesis yang menunjukkan bahwa nilai $t_{\text {hitung }}$ lebih kecil dari $t_{\text {tabel }}$ pada taraf signifikansi 0,05 . Dengan demikian struktur modal bukan merupakan prediktor yang baik untuk menjelaskan nilai perusahaan. Perkembangan nilai perusahaan tidak mempengaruhi penilaian investor terhadap perusahaan yang terdaftar dalam indeks LQ-45 di Bursa Efek Indonesia Tahun 2015 - 2017.

Hasil penelitian ini mendukung hasil penelitian sebelumnya yang dilakukan oleh Sudiani dan Wiksuana (2018) yang mengungkapkan bahwa struktur modal perusahaan tidak bepengaruh terhadap nilai perusahaan. Hasil penelitian ini juga mendukung penelitian yang dilakukan oleh Hadiwijaya et.al (2016 yang juga mengungkapkan bahwa struktur modal tidak berpengaruh signifikan terhadap nilai perusahaan. Sementara itu hasil penelitian ini membantah penelitian yang dilakukan oleh Susanti dan Restiana (2018) yang justru mengungkapkan bahwa struktur modal berpengaruh positif dan signifikan terhadap nilai perusahaan. Penelitian ini juga membantah penelitian yang dilakukan oleh Paminto et.al (2016) yang mengungkapkan bahwa struktur modal berpengaruh negatif dan signifikan terhadap nilai perusahaan.

Struktur modal adalah rasio antara total utang dengan modal perusahaan. Semakin tinggi Debt to Equity Ratio (DER) menunjukkan total utang (jangka pendek atau jangka panjang) lebih besar bila dibandingkan dengan modal perusahaan, sehingga dapat berdampak pada beban perusahaan kepada eksternal atau kreditur. Debt to Equity Ratio (DER) mencerminkan proporsi besarnya total hutang jangka panjang dengan modal sendiri. Hutang yang semakin besar menyebabkan beban perusahaan menjadi besar karena beban biaya hutang yang harus ditanggung. Semakin besar hutang akan menyebabkan prioritas perusahaan untuk membayar dividen akan semakin kecil karena keuntungan perusahaan berkurang dengan adanya biaya hutang perusahaan.

Hasil penelitian ini menunjukkan tidak adanya pengaruh yang signifikan dari struktur modal terhadap nilai perusahaan. Hal ini berarti bahwa perkembangan kebijakan struktur modal yang dilakukan oleh perusahaan tidak mempengaruhi penilaian investor terhadap kinerja perusahaan. Hal ini bisa dilihat pada perusahaan dengan nilai DER yang tinggi seperti PT. Jasa Marga (Persero) pada tahun 2017 sebesar 4,31 tetapi nilai PBV-nya di bawah rata-rata sebesar 2,53. Namun pada saat nilai DER rendah seperti terjadi pada PT. Indocement Tunggal Perkasa sebesar 0,15 , nilai PBV-nya juga rendah. Kondisi tersebut mencerminkan bahwa nilai DER yang tinggi tidak menjamin adanya penilaian yang baik dari investor, begitupun nilai DER yang rendah tidak membuat perusahaan mendapat penilaian yang positif dari investor. Oleh karena itu, tinggi rendahnya DER yang merupakan tolok ukur kebijakan struktur hutang perusahaan tidak memberikan dampak yang cukup besar pada penilaian investor mengenai kinerja perusahaan.

\subsubsection{Pengaruh Pertumbuhan Perusahaan terhadap Nilai Perusahaan pada Perusahaan LQ-45 di Bursa Efek Indonesia Tahun 2015 - 2017}

Hasil penelitian ini memperlihatkan tidak adanya pengaruh pertumbuhan perusahaan terhadap nilai perusahaan pada perusahaan LQ-45 di BEI tahun 2015 - 2017. Hal ini ditunjukkan oleh hasil pengujian hipotesis yang menunjukkan bahwa nilai thitung lebih kecil dari $t_{\text {tabel }}$ pada taraf signifikansi 0,05. Dengan demikian, pertumbuhan perusahaan bukan merupakan prediktor yang baik untuk menjelaskan nilai perusahaan, artinya bahwa adanya perkembangan nilai aset perusahaan pada setiap tahunnya belum tentu mampu meningkatkan nilai perusahaan pada perusahaan LQ-45 di BEI tahun 2015 - 2017.

Hasil penelitian ini mendukung penelitian sebelumnya yang dilakukan oleh Purwohandoko (2017) yang mengungkapkan bahwa pertumbuhan perusahaan tidak memiliki pengaruh yang signifikan terhadap nilai perusahaan. Sementara itu, penelitian ini menunjukkan hasil yang berbeda dengan penelitian yang dilakukan oleh Paminto et.al (2016) yang mengungkapkan bahwa pertumbuhan perusahaan berpengaruh negatif dan signifikan terhadap nilai perusahaan.

Penelitian ini membantah hasil penelitian sebelumnya yang dilakukan oleh Fajaria dan Isnalita (2018 yang mengungkapkan bahwa pertumbuhan perusahaan memberikan pengaruh yang positif dan signifikan terhadap nilai perusahaan. Perusahaan yang memiliki tingkat pertumbuhan tinggi menunjukkan bahwa manajemen perusahaan adalah memperluas bisnisnya atau memiliki produktivitas yang tinggi. Perusahaan yang melakukan produksi skala besar biasanya dapat memperoleh manfaat besar juga. Ini bisa menjadi sinyal positif bagi investor untuk berinvestasi, sehingga permintaan saham akan tinggi. Ini dapat mengarah pada nilai perusahaan yang lebih tinggi.

Hasil penelitian ini menunjukkan tidak adanya dampak yang cukup besar dari pertumbuhan perusahaan terhadap penilaian investor terhadap kinerja perusahaan. Peningkatan jumlah aset perusahaan yang menjadi tolok ukur pertumbuhan perusahaan tidak mejadi jaminan bahwa perusahaan mendapat penilaian yang positif dari investor. Hal ini bisa dilihat pada perusahaan dengan pertumbuhan aset yang sangat tinggi seperti pada PT. Waskita Karya (Persero) dengan nilai pertumbuhan pada tahun 2015 sebesar 141,66\%, namun nilai PBV-nya hanya sebesar 2,34. Sementara itu, perusahaan dengan pertumbuhan yang negatif seperti terjadi pada PT. Vale Indonesia pada tahun 2016 $(-10,88 \%)$, nilai PBV-nya juga cenderung rendah sebesar 1,18. Begitupun pada PT. Indofood Sukses 
Makmur pada tahun 2016 dengan nilai pertumbuhan negatif $(-10,52 \%)$, nilai PBV-nya juga cenderung rendah sebesar 1,55. Kondisi tersebut menunjukkan bahwa tingginya rendahnya pertumbuhan perusahaan tidak memberikan jaminan bahwa perusahaan tersebut akan mendapat penilaian yang positif dari investor.

Pertumbuhan aset yang menjadi tolok ukur pertumbuhan perusahaan tidak menjadi jaminan bahwa perusahaan memiliki kinerja yang positif. Aset merupakan total modal yang dimiliki yang terdiri dari modal sendiri yang diwakili dengan sejumlah lembar saham, dan modal yang berasal dari luar perusahaan dalam bentuk hutang jangka panjang dan jangka pendek. Apabila pertumbuhan perusahaan itu dikarenakan adanya peningkatan modal sendiri yang dimiliki oleh perusahaan, besar kemungkinan perusahaan tersebut akan mendapat respon positif dari investor. Namun dalam kenyataannya, perusahaan dengan tingkat pertumbuhan jumlah aset yang besar, peningkatan justru terjadi dari peningkatan jumlah hutang perusahaan. Peningkatan jumlah liabilitas tentunya akan menjadi beban bagi perusahaan sehingga perusahaan harus membayar beban tersebut dari laba yang diperoleh pada setiap tahunnya. Kondisi ini mengakibatkan semakin kecilnya kebijakan pembagian dividen bagi pemilik modal sehingga akan menurunkan respon investor di pasar bursa terhadap saham perusahaan.

\subsubsection{Pengaruh Profitabilitas terhadap Nilai Perusahaan pada Perusahaan LQ-45 di Bursa Efek Indonesia Tahun 2015 - 2017}

Hasil penelitian ini telah dibuktikan bahwa secara parsial profitabilitas berpengaruh positif dan signifikan terhadap nilai perusahaan. Hal ini diperlihatkan oleh hasil pengujian hipotesis yang menunjukkan menunjukkan bahwa nilai $t_{\text {hitung }}$ lebih besar dari $t_{\text {tabel }}$ pada taraf signifikansi 0,05. Dengan demikian bahwa profitabilitas mampu menjadi prediktor yang baik dalam menjelaskan nilai perusahaan yang berarti bahwa semakin tinggi proporsi laba terhadap jumlah ekuitas mampu meningkatkan nilai perusahaan pada perusahaan LQ-45 di Bursa Efek Indonesia Tahun 2015 - 2017.

Hasil penelitian ini mendukung penelitian sebelumnya yang dilakukan oleh Fajaria dan Isnalita yang mengungkapkan bahwa profitabilitas yang tinggi meningkatkan nilai perusahaan. Hasil penelitian ini juga mendukung penelitian sebelumnya yang dilakukan oleh Putu et.al (2014), Sabirin et.al (2016), Sucuahi dan Cambarihan (2016), Paminto et.al (2016), Cheryta et.al (2017), Tahu dan Susilo (2017), dan Sudiani dan Wiksuana (2018) yang mengungkapkan bahwa profitabilitas berpengaruh positif dan signifikan terhadap nilai perusahaan.

Hasil penelitian ini menunjukkan bahwa semakin besar profitabilitas perusahaan maka perusahaan tersebut akan mendapat respon positif dari investor sehingga nilai perusahaan mengalami peningkatan. Kondisi ini bisa dilihat dari perusahaan dengan nilai profitabilitas yang tinggi seperti PT. Matahari Department Store sebesar 160,99\%, nilai PBV-nya juga tergolong tinggi sebesar 46,43. Kondisi tersebut juga terlihat pada PT. Unilever Indonesia pada tahun 2016 dan 2017 dengan profitabilitas sebesar 135,85\% dan $135,40 \%$, nilai PBV-nya juga tinggi sebesar 46,67 dan 82,44. Sebaliknya pada perusahaan dengan profitabilitas rendah dengan nilai negatif seperti terjadi pada PT. Vale Indonesia 2017 dengan profitabilitas sebesar $-0,87 \%$, nilai PBV-nya juga cenderung rendah sebesar 1,17. Kondisi tersebut menggambarkan bahwa tingginya rendahnya profitabilitas perusahaan sangat menentukan nilai perusahaan yang ditunjukkan oleh tinggi rendahnya nilai PBV.

Profitabilitas adalah rasio dari efektifitas manajemen berdasarkan hasil pengembalian yang dihasilkan dari penjualan dan investasi. Dalam penelitian ini rasio profitabilitas diukur dengan return on equity (ROE) (Sartono, 2010). Return on equity (ROE) merupakan rasio yang menunjukkan kemampuan perusahaan dalam menghasilkan laba bersih untuk pengembalian ekuitas pemegang saham. ROE merupakan rasio keuangan yang digunakan untuk mengukur profitabilitas dari ekuitas.Semakin besar hasil ROE maka kinerja perusahaan semakin baik.

Brigham (2001) menjelaskan bahwa profitabilitas merupakan determinan utama sebagai pertimbangan pembayaran deviden. Semakin tinggi profitabilitas menunjukkan semakin baik manajemen dalam menjalankan operasi perusahaan. Perusahaan yang memiliki profitabilitas yang tinggi biasanya akan membagikan deviden yang tinggi pula. Myron Gordon dan John Lintner (1959) dalam Brigham (2001), menyatakan bahwa nilai perusahaan akan dimaksimumkan oleh rasio pembayaran deviden yang tinggi, karena investor menganggap bahwa resiko deviden tidak sebesar kenaikan biaya modal, sehingga investor lebih menyukai keuntungan dalam bentuk deviden daripada keuntungan yang diharapkan dari kenaikan nilai modal.

\subsubsection{Pengaruh Struktur Modal, Pertumbuhan Perusahaan dan Profitabilitas terhadap Nilai Perusahaan pada Perusahaan LQ-45 di Bursa Efek Indonesia Tahun 2015 - 2017}

Hasil penelitian ini telah dibuktikan bahwa secara bersama-sama struktur modal, pertumbuhan perusahaan, dan profitabilitas berpengaruh signifikan terhadap nilai perusahaan. Hal ini diperlihatkan oleh hasil pengujian hipotesis yang menunjukkan menunjukkan bahwa nilai $F_{\text {hitung }}$ lebih besar dari $F_{\text {tabel }}$ pada taraf signifikansi 0,05. Dengan demikian bahwa secara bersama-sama, struktur modal, pertumbuhan perusahaan dan profitabilitas mampu menjelaskan dengan baik nilai perusahaan. Hal ini berarti bahwa perkembangan struktur modal yang diikuti oleh pertumbuhan perusahaan dan peningkatan profitabilitas akan memberikan efek yang positif dalam meningkatkan nilai perusahaan pada perusahaan LQ-45 di Bursa Efek Indonesia Tahun 2015 - 2017.

Kebijakan struktur modal yang dilakukan oleh perusahaan tidak bisa berdiri sendiri dalam mempengaruhi nilai perusahaan. Kebijakan struktur modal yang lebih bergantung pada pendanaan yang 
berasal dari luar perusahaan akan menjadi beban bagi perusahaan. Kebijakan tersebut akan membuat perusahaan mengurangi pembagian dividen karena digunakan untuk membayar beban untuk kebutuhan pendanaan perusahaan. Pada sisi lain, perusahaan dengan struktur modal yang kuat akan memberikan jaminan bahwa perusahaan tersebut mampu menjalankan kegiatan operasionalnya dengan baik sehingga akan menghasilkan tingkat keuntungan yang besar. Oleh sebab itu, kebijakan struktur modal yang dilakukan harus diiringi dengan peningkatan jumlah laba yang dihasilkan oleh perusahaan sehingga kebijakan struktur modal memberikan efek yang signifikan terhadap kinerja perusahaan.

Pertumbuhan perusahaan yang diukur menggunakan perkembangan aset perusahaan tidak menjamin bahwa perusahaan dalam kondisi yang baik. Perusahaan dengan jumlah aset yang tinggi, namun aset tersebut didominasi oleh tingkat liabilitas yang tinggi membuat perusahaan rentan terhadap likuidasi karena tidak mampu menjamin hutang yang dimilikinya dengan permodalan yang dimiliki oleh perusahaan. Perusahaan yang tumbuh dikarenakan kebijakan struktur modal perusahaan yang mengutamakan peningkatan hutang perusahaan dibandingkan dengan peningkatan jumlah modal sendiri tentunya akan memberikan efek yang negatif terhadap kinerja perusahaan. Sebaliknya jika pertumbuhan perusahaan itu dipengaruhi oleh peningkatan jumlah ekuitas perusahaan, maka kondisi tersebut menunjukkan bahwa perusahaan tersebut mampu berjalan dengan baik dan berhasil menghasilkan laba yang cukup besar sehingga menambah nilai modal sendiri perusahaan.

Berdasarkan hasil penelitian ini jelas bahwa kebijakan struktur modal harus mengutamakan pada sumber pendanaan yang berasal dari modal sendiri dan mengurangi jumlah liabilitas perusahaan. Peningkatan aset perusahaan dikarenakan adanya penambahan jumlah modal sendiri menunjukkan bahwa perusahaan tumbuh secara sehat dalam arti pertumbuhan perusahaan tersebut tidak diiringi oleh peningkatan jumlah beban perusahaan. Perusahaan yang tumbuh baik tanpa dibebani oleh hutang yang besar yang harus dibayar setiap tahunnya akan mampu menghasilkan tingkat laba yang positif. Pergerakan struktur modal yang efektif yang berfokus pada modal sendiri akan membuat perusahaan tumbuh secara psotif tanpa dibebani hutang, dan perusahaan tersebut akan mencapai tingkat profitabilitas yang tinggi. Ketiga kondisi tersebut yang saling menunjang satu sama lain akan memberikan efek nilai perusahaan.

\section{SIMPULAN DAN SARAN}

\subsection{Simpulan}

Berdasarkan hasil penelitian dapat disimpulkan hal-hal sebagai berikut:

1. Struktur modal, pertumbuhan perusahaan, dan profitabilitas berpengaruh signifikan terhadap nilai perusahaan yang berarti bahwa secara bersama- sama struktur modal, pertumbuhan perusahaan, dan profitabilitas mampu menjelaskan dengan baik nilai perusahaan pada perusahaan LQ-45 di Bursa Efek Indonesia Tahun 2015 - 2017.

2. Struktur modal tidak memiliki pengaruh yang signifikan terhadap nilai perusahaan pada perusahaan LQ-45 di Bursa Efek Indonesia Tahun 2015 - 2017.

3. Pertumbuhan perusahaan tidak memiliki pengaruh yang signifikan terhadap nilai perusahaan pada perusahaan LQ-45 di Bursa Efek Indonesia Tahun 2015 - 2017.

4. Profitabilitas memiliki pengaruh positif dan signifikan terhadap nilai perusahaan pada perusahaan LQ-45 di Bursa Efek Indonesia Tahun 2015 - 2017.

\subsection{Saran}

Berdasarkan kesimpulan hasil penelitian ini sebagaimana diuraikan di atas, maka peneliti menyumbangkan saran sebagai berikut:

1. Perusahaan LQ-45 di BEI tahun 2015 - 2017 supaya meningkatkan profitabilitas perusahaan dengan melakukan efisiensi operasional perusahaan sehingga diharapkan akan berdampak pada penilaian yang positif dari investor dan akan meningkatkan harga saham di bursa efek.

2. Perusahaan LQ-45 di BEI tahun 2015 - 2017 supaya mengurangi ketergantungan permodalan perusahaan pada hutang sehingga kegiatan operasional benarbenar berasal dari modal sendiri yang dimiliki oleh perusahaan.

3. Bagi peneliti selanjutnya supaya melakukan penelitian dengan subjek penelitian yang lebih besar dan lebih beragam misalnya dengan menggunakan perusahaan manufaktur atau seluruh perusahaan yang ada di Bursa Efek Indonesia.

4. Bagi peneliti selanjutnya supaya menggunakan periode penelitian yang lebih panjang dan menambahkan variabel-variabel lain yang mempengaruhi nilai perusahaan seperti tata kelola perusahaan, pengungkapan informasi dalam laporan keuangan, struktur kepemilikan saham, faktorfaktor makro ekonomi dan lain sebagainya.

\section{DAFA R REFERENSI}

Andhika S. D. K., Rizky Dwi P., Hasan, M., dan Fadah, I. 2018. Capital Structure, Profitability, and Firm Values. International Journal of Scientific \& Technology Research Volume 7, Issue 12, December 2018.

Antwi, S., Mills, E.F.E.A., dan Zhao, X. 2012. Capital Structure and Firm Value: Empirical Evidence from Ghana. International Journal of Business and Social Science Vol. 3 No. 22 [Special Issue November 2012]. 
Bernard, B., S, H, Jang dan W Kim. (2003), "Does Corporate Governance affect Firm Value? Evidence from Korea”, http://papers. ssrn.com.

Cheryta, A.M., Moeljadi, dan Indrawati, N.K. 2017. The Effect of Leverage, Profitability, Information Asymmetry, Firm Size on Cash Holding and Firm Value of Manufacturing Firms Listed at Indonesian Stock Exchange. International Journal of Research in Business Studies and Management Volume 4, Issue 4, 2017, PP 21-31 ISSN 23945923 (Print) \& ISSN 2394-5931 (Online) http://dx.doi.org/10.22259/ijrbsm.0404004.

Dewi Putu Yunita Saputri, Gede Adi Yuniarta, Ananta Wikrama Tungga Atmadja, 2014, Pengaruh Strukur Modal, Profitabilitas dan Ukuran Perusahaan Pada Nilai Perusahaan, E-Journal S1 Ak Universitas Pendidikan Ganesha Jurusan Akuntansi S1, Volume 2 No: 1

Fahmi, Irham. 2011. Analisa Laporan Keuangan. Bandung: Alfabeta.

Fahmi, Irham. 2014. Corporate Financial Management and Capital Markets. Issue 1. Jakarta: Publisher Partners Media Discourse.

Fajaria, A.Z dan Isnalita. 2018. The Effect of Profitability, Liquidity, Leverage and Firm Growth of Firm Value with its Dividend Policy as a Moderating Variable. International Journal of Managerial Studies and Research (IJMSR) Volume 6, Issue 10, October 2018, PP 55-69 ISSN 2349-0330 (Print) \& ISSN 2349-0349 (Online) http://dx.doi.org/10.20431/2349-0349.0610005.

Hadiwijaya, T., Lahindah, L., dan Pratiwi, I.R. 2016. Effect of Capital Structure and Corporate Governance on Firm Value (Study of Listed Banking Companies in Indonesia Stock Exchange). Journal of Accounting and Business Studies Vol. 1, No. 1, September 2016.

Hartono, Jogiyanto, (2009), Teori Portofollio dan Analisis Investasi, Edisi kelima, Yogyakarta: BPFE.

Haryetty dan Ririn Araji Ekayanti, 2012, Pengaruh Profitabilitas, Investment Opportunity Set dan Pertumbuhan Perusahaan Terhadap Kebijakan Deviden Pada perusahaan LQ-45 Yang Terdaftar Di BEI,Jurnal Ekonomi Vol, 20 No,3 Universitas Riau Kampus Bina Wydia.

Husnan Suad dan Enny Pudjiastuti, 2006, Dasar-dasar manajemen keuangan, Edisi ke-5, penerbit UPP STIM YKPN, Yogyakarta.

Jogiyanto, Hartono, 2009, Teori Portofolio Dan Analisis Investasi, Yogyakarta: BPFE.

Kusumajaya, Dewa Kadek Oka, 2011,Pengaruh Struktur Modal Dan Pertumbuhan Perusahaan Terhadap Profitabilitas Dan Nilai Perusahaan Pada Perusahaan Manufaktur Di Bursa Efek Indonesia, Tesis S2, Universitas Udayana, (online), (www.google.com).
Mulyadi, 2007, Activity-Based Costing System.edisi keenam, cetakan kedua. BPFE, Yogyakarta.

Novianto Nico Hwrnando, 2016, Pengaruh Profitabilitas dan Pertumbuhan Manajemen, Volume 52, No. 11, Universitas Tarumanagara.

Paminto, A., Setyadi, D dan Sinaga, J. 2016. The Effect of Capital Structure, Firm Growth and Dividend Policy on Profitability and Firm Value of the Oil Palm Plantation Companies in Indonesia. European Journal of Business and Management www.iiste.org ISSN 2222-1905 (Paper) ISSN 2222-2839 (Online Vol.8, No.33, 2016.

Purwohandoko. 2017. The Influence of Firm's Size, Growth, and Profitability on Firm Value with Capital Structure as the Mediator: A Study on the Agricultural Firms Listed in the Indonesian Stock Exchange. International Journal of Economics and Finance; Vol. 9, No. 8; 2017 https://doi.org/10.5539/ijef.v9n8p103.

Putu, N.N.G.M., Moeljadi, Djumahir, dan Djazuli, A. 2014. Factors Affecting Firms Value of Indonesia Public Manufacturing Firms. International Journal of Business and Management Invention ISSN (Online): 2319 - 8028, ISSN (Print): 2319 $801 X$ www.ijbmi.org Volume 3 Issue 2\| February. 2014|| PP.35-44.

Sabrin, Sarita, B., Takdir. S.D., dan Sujono. 2016. The Effect of Profitability on Firm Value in Manufacturing Company at Indonesia Stock Exchange. The International Journal of Engineering and Science (IJES) Volume 5 Issue 10 Pages PP 81-89 ISSN (e): 2319 - 1813 ISSN (p): $2319-1805$.

Setiawan Feri dan Bambang Suryono, 2015, Pengaruh Pertumbuhan Perusahaan,Profitabilitas, Likuiditas dan Leverage Terhadap Opini Audit Going Concern, Jurnal Ilmu dan Riset Akuntansi Vol, 4 No,3, STIESIA Surabaya.

Sucuahi, W dan Cambarihan, J.M. 2016. Influence of Profitability to the Firm Value of Diversified Companies in the Philippines. Accounting and Finance Research Vol. 5, No. 2; 2016 http://dx.doi.org/10.5430/afr.v5n2p149.

Sudana, 2008, ’Pengaruh Struktur Kepemilikan Saham, Struktur Modal dan Profitabilitas Pada Nilai Perusahaan, Tesis,Kadek Apriada, Fakultas Ekonomi Jurusan Akuntansi, hlm 221, Universitas Udayana Denpasar Tahun 2013.

Sudiani, N.K.A., Wiksuana I G.B. 2018. Capital Structure, Investment Opportunity Set, Dividend Policy and Profitability as a Firm Value Determinants. RJOAS, 9(81), September 2018 https://doi.org/10.18551/rjoas.2018-09.30.

Susanti, N., \& Restiana, N. G. 2018. What's the best factor to determining firm value? Jurnal Keuangan dan Perbankan, 22(2), 301-309. https://doi.org/10.26905/jkdp.v22i2.1529. 
Swardika I Nyoman Agus, 2017, Pengaruh Leverage, Ukuran Perusahaan, Pertumbuhan Perusahaan dan Profitabilitas Terhadap Nilai Perusahaan Pada Perusahaan Properti, E-Jurnal Manajemen Unud, Vol, 6, No, 3, Universitas Udayana Bali.

Tahu, G.P dan Susilo, D.D.B. 2017. Effect of Liquidity, Leverage and profitability to The Firm Value (Dividend Policy as Moderating Variable) in Manufacturing Company of Indonesia Stock Exchange. Research Journal of Finance and Accounting www.iiste.org ISSN 2222-1697 (Paper) ISSN 2222-2847 (Online) Vol.8, No.18, 2017. 